\title{
Chemical composition of forage and feces as affected by microwave oven drying
}

\section{J.F. KARN}

\section{Abstract}

Freeze drying, conventional oven drying, and microwave oven drying were compared with respect to their effect on the chemical composition of native range forage and feces from cattle graxing the forage. Forage was collected by hand harvesting and by esophageal-fistulated steers (extrusa) on 10 collection dates from 11 June to 15 Oct. in 1987 and on 6 collection dates from 2 June to 15 Sept. in 1988. Composite fecal samples were obtained from cattle grazing the same pastures the day following forage collections.

Drying method had minimal effect on in vitro digestible organic matter (IVDOM), ash, neutral detergent fiber (NDF), nitrogen, and ash insoluble in neutral detergent (AIND) in hand clipped native forage. However, both microwave and conventional oven drying of extrusa resulted in greater NDF than freeze drying. Unexpectedly, IVDOM in microwave oven dried extrusa was equal to or greater than values for freeze dried material. There were no interactions between drying method and sampling date for any components measured in the extrusa. Microwave and conventional oven drying of feces resulted in greater NDF values than freeze drying, with microwave drying resulting in significantly greater NDF than conventional oven drying. There was also more AIND in heat dried feces, but nitrogen and ash levels were not affected by drying method. The data indicate that if nitrogen or ash are to be determined in hand clipped forage, extrusa, or feces, then microwave or conventional oven drying is acceptable; but if fiber levels are to be determined in these materials, then it appears they should be freeze dried for the most accurate results.

\section{Key Words: freeze drying, oven drying, extrusa, native range}

Rapid and efficient drying of forage and fecal materials without chemical change or dry matter loss is a fundamental concern of range animal scientists. Dry matter losses from forage and feces due to oven drying can occur (Raymond and Harris 1954). High temperature drying causes condensation of sugar residues with

\footnotetext{
Author is a research animal scientist, USDA-ARS. Northern Great Plains Research Laboratory, P.O. Box 459, Mandan, North Dakota 58554.

Author wishes to thank Dr. Gary V. Richardson, mathematical statistician, for assistance with statistical procedures and Mr. Richard E. Huppler and Mrs. Linda Jensen for technical assistance.

Mention of a trade name is solely to identify equipment used and does not constitute endorsement by the USDA.

Manuscript accepted 6 March 1990.
}

amino acids, i.e., heat damage that results in the formation of Maillard products which have physical properties similar to lignin (Van Soest 1982). Conversely, drying forage at low temperature, especially when it has been collected from fistulated animals, may result in organic matter losses due to continued respiration (Acosta and Kothmann 1978).

Freeze drying is considered the most appropriate method for drying forage (Raguse and Smith 1965) and extrusa samples (Smith et al. 1967). Microwave oven drying, which is based on excitation of water and fat molecules to a point where agitation produces heat, has been used to dry forage samples (Hofman 1965, Jones and ap Griffith 1968, Higgins and Spooner 1986). Karn (1986) used microwave drying in combination with low temperature conventional oven drying to prevent respiration and fermentation losses in extrusa. However, the results were inconsistent for in vitro digestible organic matter between spring and fall extrusa samples. The author is not aware of any published research on the effects of microwave oven drying on fecal chemical composition.

The primary objective of this study was to compare the effect of microwave oven drying, conventional oven drying, and freeze drying on the chemical composition of hand clipped forage, extrusa, and feces. A secondary objective was to determine whether drying methods were consistent over sampling dates with respect to their effects on chemical composition.

\section{Materials and Methods}

Native pastures rotationally grazed with cow-calf pairs were sampled every 2 weeks in 1987, from 11 June to 15 October, for a total of 10 sampling dates. In 1988 native pastures rotationally grazed with yearling steers were sampled every 3 weeks from 2 June to 15 September for a total of 6 sampling dates. Species present in the pastures were western wheatgrass [ Pascopyrum smithii (Rydb.) Löve], blue grama [Bouteloua gracilis (H.B.K.) Griffiths], Kentucky bluegrass ( Poa pratensis L.), upland sedges (Carex species), needleandthread (Stipa comata Trin. and Rupr.), green needlegrass (Stipa viridula Trin.), leadplant (Amorpha canescens Pursch), green sageworth (Artemisia campestris L.), and cudweed sagewort (Artemisia ludoviciana Nutt.). Pasture samples were collected with 3 esophageal-fistulated steers (extrusa) and hand clipped by 2 
individuals. Hand clipped samples were obtained by selecting plants and plant parts that were representative of forage being grazed (Karn and Hofmann 1990). Composite fecal samples were collected from 4 different groups of cattle grazing the study pastures the day after forage collections were made. Fecal samples were collected immediately after defecation. All materials were brought to the laboratory within 2 hours. Each extrusa, hand clipped forage, or fecal sample was separated into 3 subsamples for a total of 9 extrusa, 6 hand clipped foraged, and 12 fecal samples per date. Subsamples were randomly assigned to 1 of the following drying methods: freeze drying, conventional forced air oven drying at $50^{\circ} \mathrm{C}$, or microwave oven drying followed by conventional oven drying at $50^{\circ} \mathrm{C}$. The microwave plus conventional oven drying method will henceforth be referred to as the microwave method. Extrusa and fecal samples were microwave dried for $30 \mathrm{~min}$ based on previous data for high moisture material (Karn 1986). Hand clipped forage samples were microwave oven dried for $8 \mathrm{~min}$ based on the weight of hand clipped forage relative to the wet sample weight and drying time ( $30 \mathrm{~min}$ ) of the extrusa. A microwave oven ${ }^{1}$ with a 650-W output was used for all microwave drying. A beaker containing $300 \mathrm{ml}$ of water was kept in the oven during drying to protect the magnetrons from excessive reflected radiation. The oven chamber was large enough to accommodate 4 samples in $13 \times$ $20 \times 2 \mathrm{~cm}$ plastic pans. Three replicate $350 \mathrm{~g}$ extrusa samples or 4 replicate $290 \mathrm{~g}$ fecal samples were dried concurrently. Two replicate hand clipped samples of approximately $140 \mathrm{~g}$ were dried together in $15 \times 15 \times 13 \mathrm{~cm}$ plastic containers. All microwave dried samples were rotated midway through drying to provide equal radiation exposure. After microwave drying, extrusa samples were mixed, placed in an aluminum tray and dried at $50^{\circ} \mathrm{C}$ to a constant weight in a conventional forced air oven ${ }^{2}$. Conventional oven dried samples were also mixed at this time and dried to a constant weight. Samples to be freeze dried were frozen at $-15^{\circ} \mathrm{C}$ and stored until drying ${ }^{3}$ could be completed.

After drying, all samples were ground to pass a $1-\mathrm{mm}$ screen. Nitrogen was determined with an autoanalyzert following wet oxidation of the organic matter (Schuman et al. 1973). In vitro digestible organic matter (IVDOM) was determined on hand clipped and extrusa samples by the Tilley and Terry (1963) procedure as modified by Moore and Mott (1974). Neutral detergent fiber (NDF) and ash insoluble in neutral detergent (AIND) were determined by the procedures of Goering and Van Soest (1970). Ash was determined by combusting samples in a muffle furnace at $500^{\circ} \mathrm{C}$ for 5 hours.

Data were analyzed separately for each year by method of collection subgroup, because of highly significant differences in variances among these subclasses. Analysis of variance procedures within year and method of collection were used to evaluate the effects of date, replicates, drying method, and the drying method by date interactions. Replicates consisted of 3 steers, 4 group composites, or 2 individuals for extrusa, fecal, or hand clipped methods of collection, respectively. Significant treatment means were compared by the Student-Newman-Keuls' test with differences considered significant at the $5 \%$ probability level.

\section{Results and Discussion}

In both years, sampling dates for all components measured in hand clipped, extrusa, and fecal samples differed $(P<0.05)$ except for AIND in hand clipped forage in 1988 (data not shown). The only chemical component among collection methods either year with a significant $(P<0.05)$ interaction between drying method and

\footnotetext{
'Magic Chef, Magic Chef, Inc., Anniston, Ala.

2Blue M, Blue M Electric Co., Blue Island, III.

${ }^{3}$ Virtis Freeze Dryer, The Virtis Co., Inc., Gardiner, N.Y.

'Technicon Industrial Systems, Tarrytown, N.Y.
}

sampling date was fecal NDF in 1987. This indicates that forage collected during different seasons with consequent differences in chemical composition reacted similarly to drying methods.

\section{Hand Clipped Forage}

Hand clipped native forage that was microwave dried had significantly lower IVDOM and higher NDF than freeze dried forage in 1987, but microwave drying had no effect on IVDOM or NDF in 1988 (Table 1). In 1987 there were no differences in IVDOM

Table 1. Effect of drying method on the chemical composition of hand clipped forage, averaged across dates. ${ }^{1}$

\begin{tabular}{|c|c|c|c|c|c|}
\hline $\begin{array}{l}\text { Drying } \\
\text { method }\end{array}$ & IVDOM $^{2}$ & Ash & Nitrogen & $\mathrm{NDF}^{2}$ & AIND $^{2}$ \\
\hline & $\mathrm{g} \mathrm{kg}^{-1}$ & \multicolumn{4}{|c|}{$\ldots \ldots \mathrm{g} \mathrm{kg}^{-1} \mathrm{dry}$ basis $\ldots \ldots 87$} \\
\hline $\begin{array}{l}\mathrm{FD}^{3} \\
\mathrm{OD}^{3} \\
\mathrm{MW}^{3}\end{array}$ & $\begin{array}{l}585 \mathrm{a}^{4} \\
574 \mathrm{ab} \\
570 \mathrm{~b}\end{array}$ & $\begin{array}{l}95.8 \\
95.8 \\
95.2\end{array}$ & $\begin{array}{l}19.0 \\
19.3 \\
19.4\end{array}$ & $\begin{array}{l}633 a \\
650 b \\
657 b\end{array}$ & $\begin{array}{l}29.5 \\
31.0 \\
31.0\end{array}$ \\
\hline \multirow[t]{2}{*}{$\mathrm{SE}^{5}$} & 0.9 & 0.2 & 0.09 & 1.3 & 0.1 \\
\hline & & & 1988 & & \\
\hline $\begin{array}{l}\mathrm{FD}^{3} \\
\mathrm{OD}^{3} \\
\mathrm{MW}^{3}\end{array}$ & $\begin{array}{l}595 \\
589 \\
593\end{array}$ & $\begin{array}{l}90.6 \\
91.0 \\
90.7\end{array}$ & $\begin{array}{l}17.8 \\
17.9 \\
17.7\end{array}$ & $\begin{array}{l}662 \\
670 \\
665\end{array}$ & $\begin{array}{l}32.7 \\
35.6 \\
32.8\end{array}$ \\
\hline SE $^{s}$ & 0.9 & 0.3 & 0.05 & 2.3 & 0.9 \\
\hline
\end{tabular}

1Means represent an average of 20 values in 1987 and 12 values in 1988.

${ }^{2}$ IVDOM = in vitro digestible organic matter, NDF = neutral detergent fiber, $A I N D=$ ash insoluble in neutral detergent.

${ }^{3} \mathrm{FD}=$ freeze dried, $\mathrm{OD}=$ conventional oven dried at $50^{\circ} \mathrm{C}, \mathrm{MW}=$ microwave oven dried for $8 \mathrm{~min}$ followed by conventional oven drying at $50^{\circ} \mathrm{C}$.

4 Means within columns and years without a common letter differ $(P<0.05)$.

sStandard error of the mean $=\frac{\sqrt{\mathbf{E M S}}}{\mathbf{N}}$, where EMS = error

mean square used to test treatments and $\mathrm{N}=$ the number of observations $/$ mean.

between conventional oven dried and freeze dried forage, but conventional oven dried forage was significantly higher in NDF than freeze dried forage. Ash, AIND, and nitrogen were not affected by method of drying either year. Microwave drying or predrying of plant material has previously been reported to result in nitrogen levels comparable to conventional oven drying (Kaldy et al. 1979, Schuman and Rauzi 1981, Higgins and Spooner 1986). Levels of water soluble carbohydrates (Jones and ap Griffith 1968) and total nonstructural carbohydrates (Wolf and Carson 1973) were reported to be similar in freeze dried and microwave dried or predried forage, while levels of these constituents were significantly reduced by conventional oven drying at $70^{\circ} \mathrm{C}$ (Wolf and Carson 1973).

\section{Extruse}

Microwave and freeze dried extrusa had from 2 to $6 \%$ more IVDOM than conventional oven dried material in 1987 and 1988. In 1988 microwave dried forage had the highest IVDOM (Table 2). This is in agreement with previous data (Karn 1986) for fall collected forage obtained via fistulated animals. Burritt et al. (1988) reported that IVDMD in extrusa samples was generally depressed by oven- and air-drying, with the effect being greatest in samples containing phenolic compounds. Neutral detergent fiber in the present study was higher in conventional and microwave oven dried samples compared to freeze dried samples in both 1987 and 1988. Similar results were reported by Burritt et al. (1988) for oven dried extrusa from immature but not mature forage.

The apparent contradiction of increased NDF yet equal to or greater IVDOM in microwave dried extrusa may be explained by the results of Allan et al. (1980), which showed that high-intensity microwave energy degraded cellulose. Azuma et al. (1984) also 
Table 2. Effect of drying method on the chemical composition of extrusa, averaged across dates."

\begin{tabular}{|c|c|c|c|c|c|}
\hline $\begin{array}{l}\text { Drying } \\
\text { method }\end{array}$ & IVDOM $^{2}$ & Ash & Nitrogen & $\mathrm{NDF}^{2}$ & AIND $^{2}$ \\
\hline & $\mathrm{g} \mathrm{kg}^{-1}$ & \multicolumn{4}{|c|}{ 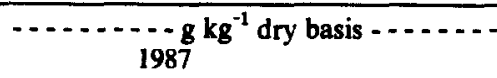 } \\
\hline $\begin{array}{l}\mathrm{FD}^{3} \\
\mathrm{OD}^{3} \\
\mathrm{MW}^{3}\end{array}$ & $\begin{array}{l}601 \mathrm{a}^{4} \\
567 \mathrm{~b} \\
598 \mathrm{a}\end{array}$ & $\begin{array}{l}136 \\
139 \\
138\end{array}$ & $\begin{array}{l}16.1 \\
16.3 \\
16.3\end{array}$ & $\begin{array}{l}630 b \\
675 a \\
674 a\end{array}$ & $\begin{array}{l}42.3 \\
46.8 \\
47.9\end{array}$ \\
\hline $\mathrm{SE}^{5}$ & 0.49 & 0.57 & 0.03 & 0.62 & 0.55 \\
\hline $\begin{array}{l}\mathrm{FD}^{3} \\
\mathrm{OD}^{3} \\
\mathrm{MW}^{3}\end{array}$ & $\begin{array}{l}591 b \\
581 \mathrm{c} \\
615 \mathrm{a}\end{array}$ & $\begin{array}{l}147 \\
144 \\
145\end{array}$ & $\begin{array}{l}1988 \\
15.1 \\
15.0 \\
15.0\end{array}$ & $\begin{array}{l}655 \mathrm{~b} \\
708 \mathrm{a} \\
698 \mathrm{a}\end{array}$ & $\begin{array}{l}46.5 \\
52.9 \\
54.6\end{array}$ \\
\hline SE $^{5}$ & 0.81 & 0.93 & 0.03 & 0.97 & 1.02 \\
\hline
\end{tabular}

'Means represent an average of 30 values in 1987 and 18 values in 1988.

2IVDOM = in vitro digestible organic matter, NDF = neutral detergent fiber, AIND = ash insoluble in neutral detergent.

${ }^{3} \mathrm{FD}=$ freeze dried, $\mathrm{OD}=$ conventional oven dried at $50^{\circ} \mathrm{C}, \mathrm{MW}=$ microwave oven dried for $30 \mathrm{~min}$ followed by conventional oven drying at $50^{\circ} \mathrm{C}$.

${ }^{4}$ Means within columns and years without a common letter differ $(P<0.05)$.

s'Standard error of the mean $=\frac{\sqrt{\text { EMS }}}{\mathbf{N}}$, where EMS $=$ error

mean square used to test treatments and $\mathrm{N}=$ the number of observations $/$ mean

reported that microwave heating of lignocellulosic wastes enhanced their susceptibility to enzymatic activity. However, Erdman and Monson (1986) found that IVDMD was generally lower in microwave treated agricultural wastes. Carlier and Van Hee (1971) reported higher IVDOM and lower crude fiber in microwave than in conventional oven dried grass and alfalfa.

Ash, nitrogen, and AIND in extrusa were not affected by drying method (Table 2), which is an agreement with the data for hand clipped forage (Table 1) and with data previously reported by Karn (1986) for extrusa. Comparable ash levels among drying methods suggest there were no differences in organic matter losses among methods. Acosta and Kothmann (1978) reported organic matter losses of $9 \%$ in oven dried compared to freeze dried extrusa samples.

\section{Feces}

Fecal ash was slightly, but significantly $(P<0.05)$ increased $(1 \%)$ by conventional oven drying compared to freeze drying or microwave oven drying in 1987, but there were no differences in ash among methods in 1988 (Table 3). There were no differences in nitrogen among drying methods in either 1987 or 1988 . Hinnant and Kothmann (1988) also reported nitrogen levels in freeze dried and oven dried (at $60^{\circ} \mathrm{C}$ ) feces were comparable. However, Raymond and Harris (1954) reported a 5-10\% loss of fecal nitrogen in conventional oven dried material compared to levels in fresh feces. Neutral detergent fiber in feces was significantly different among all 3 drying methods with freeze dried feces having the lowest NDF and microwave dried feces having the highest NDF. This indicates that even low temperature $\left(50^{\circ} \mathrm{C}\right)$ drying of feces resulted in the formation of Maillard products. Ash insoluble in neutral detergent was also significantly higher in conventional oven and microwave oven dried feces, suggesting that during heat drying some minerals complexed with fiber raising NDF and AIND, presumably due to decreased solubility of affected minerals in the neutral detergent solution.

\section{Conclusions}

Chemical composition changes in forage and extrusa samples due to drying method were similar at all sampling dates. Drying method had little effect on ash or nitrogen in forage, extrusa, or
Table 3. Effect of drying method on fecal chemical composition, averaged across dates. 1

\begin{tabular}{|c|c|c|c|c|}
\hline $\begin{array}{l}\text { Drying } \\
\text { method }\end{array}$ & Ash & Nitrogen & $\mathrm{NDF}^{2}$ & $\mathrm{AIND}^{2}$ \\
\hline & \multicolumn{4}{|c|}{$\begin{array}{c}1987 \\
0.19\end{array}$} \\
\hline $\begin{array}{l}\mathrm{FD}^{3} \\
\mathrm{OD}^{3} \\
\mathbf{M W}^{3}\end{array}$ & $\begin{array}{l}173 a^{4} \\
175 b \\
173 a\end{array}$ & $\begin{array}{l}18.5 \\
18.5 \\
18.4\end{array}$ & $\begin{array}{l}596 a \\
632 b \\
638 c\end{array}$ & $\begin{array}{l}76.2 a \\
82.4 b \\
81.3 b\end{array}$ \\
\hline $\mathrm{SE}^{\mathbf{S}}$ & 0.08 & 0.02 & 0.2 & 0.08 \\
\hline $\begin{array}{l}\mathrm{FD}^{3} \\
\mathrm{OD}^{3} \\
\mathrm{MW}^{3}\end{array}$ & $\begin{array}{l}181 \\
186 \\
181\end{array}$ & $\begin{array}{l}18.2 \\
18.2 \\
18.1\end{array}$ & $\begin{array}{l}988 \\
590 \mathrm{a} \\
621 \mathrm{~b} \\
634 \mathrm{c}\end{array}$ & $\begin{array}{l}87.5 a \\
99.4 b \\
97.1 b\end{array}$ \\
\hline$S^{S}$ & 0.4 & 0.03 & 0.4 & 0.3 \\
\hline
\end{tabular}

'Means represent an average of 40 values in 1987 and 24 values in 1988. 2NDF = neutral detergent fiber, $\mathrm{AIND}=$ ash insoluble in neutral detergent.

${ }^{3} \mathrm{FD}=$ freeze dried, $\mathrm{OD}=$ conventional oven dried at $50^{\circ} \mathrm{C}, \mathrm{MW}=$ microwave oven dried for $30 \mathrm{~min}$ followed by conventional oven drying at $50^{\circ} \mathrm{C}$

4Means within columns and years without a common letter differ $(P<0.05)$

sStandard error of the mean $=\frac{\sqrt{\text { EMS }}}{N}$, where EMS = error

mean square used to test treatments and $\mathbf{N}=$ the number of observations/mean

feces, suggesting that if samples are to be analyzed for nitrogen or minerals, heat drying is acceptable. However, NDF was increased by heat (microwave or conventional oven) drying especially in extrusa and feces, indicating that if these materials are to be analyzed for fiber, they should be freeze dried. Heat drying had little effect on IVDOM in hand clipped forage. However, in extrusa, microwave oven drying resulted in IVDOM levels that were equal to or greater than levels in freeze dried material, even though NDF levels were also higher in this material. This suggests some positive effect of microwave radiation on fiber digestibility. Thus, it is obviously important to determine what analyses are to be performed before deciding how materials are to be dried.

\section{Literature Cited}

Acosta, R.A., and M.M. Kothmann. 1978. Chemical composition of esophageal-fistula forage samples as influenced by drying method and salivary leaching. J. Anim. Sci. 47:691-698.

Allan, G.G., B.B. Krieger, and D.W. Work. 1980. Dielectric loss microwave degradation of polymers: cellulose. J. Appl. Polym. Sci. 25:1839-1859.

Azuma, J., F. Tanaka, and T. Koshijima. 1984. Enhancement of enzymatic susceptibility of lignocellulosic wastes by microwave irradiation. J. Ferment. Technol. 62:377-384.

Burritt, E.A., J.A. Pfister, and J.C. Malechek. 1988. Effect of drying method on the nutritive composition of esophageal fistula forage samples: influence of maturity. J. Range Manage. 41:346-349.

Carlier, L.A., and L.P. Van Hee. 1971. Microwave drying of lucerne and grass samples. J. Sci. Food Agr. 22:306-307.

Erdman, M.D., and W.G. Monson. 1986. In vitro digestibility of selected agricultural wastes at various moisture levels treated with microwave energy. J. Agr. Food Chem. 34:889-892.

Goering, H.K., and P.J. Van Soest. 1970. Forage fiber analyses (apparatus, reagents, procedures and some applications). Agr. Handb. 379.

Higgins, T.R., and A.E. Spooner. 1986. Microwave drying of alfalfa compared to field-and oven-drying: Effects on forage quality. Anim. Feed Sci. Tech. 16:1-6.

Hinnant, R.T., and M.M. Kothmann. 1988. Collecting, drying, and preserving feces for chemical and microhistological analysis. J. Range Manage. 41:168-171.

Hofman, M.A.J. 1965. Microwave heating as an energy source for the predrying of herbage samples. Plant and Soil 23:145-148.

Jones, D.I.H., and G. ap. Griffith. 1968. Microwave drying of herbage. J. Brit. Grassl. Soc. 23:202-205.

Kaldy, M.S., M.R. Hanna, and S. Smoliak. 1979. Influence of drying methods on protein content and amino acid composition of three forage legumes. Can. J. Plant Sci. 59:707-712. 
Karn, J.F. 1986. Microwave-oven drying of forage samples collected via esophageal fistula. J. Anim. Sci. 63:595-602.

Karn, J.F., and L. Hofmann. 1990. Relationships between pasture forage components and fecal chemical composition. J. Range Manage. 43:320-325.

Moore, J.E., and G.O. Mott. 1974. Recovery of residual organic matter from in vitro digestion of forages. J. Dairy Sci. 57:1258.

Raguse, C.A., and D. Smith. 1965. Carbohydrate content in alfalfa herbage as influenced by method of drying. J. Agr. Food Chem. 13:306-309.

Raymond, W.F., and C.E. Harris. 1954. The laboratory drying of herbage and faeces, and dry matter losses possible during drying. J. Brit. Grassl. Soc. 9:119-130.
Schuman, G.E., and F. Rauzi. 1981. Microwave drying of rangeland forage samples. J. Range Manage. 34:426-428.

Schuman, G.E., M.A. Stanley, and D. Knudsen. 1973. Automated total nitrogen analysis of soil and plant samples. Soil Sci. Soc. Amer. Proc. $37: 480-481$.

Smith, T.M., A.L. Lesperance, and V.R. Bohman. 1967. Drying methods related to changes in chemical composition. Proc. West. Sec. Amer. Soc. Anim. Sci. 18:285.

Tilley, J.M.A., and R.A. Terry. 1963. A two stage technique for the in vitro digestion of forage crops. J. Brit. Grassl. Soc. 18:104-111.

Van Soest, P.J. 1982. Nutritional Ecology of the Ruminant. O and B Books, Corvallis, Ore.

Wolf, D.D., and E.W. Carson. 1973. Respiration during drying of alfalfa herbage. Crop Sci. 13:660-662. 